\begin{tabular}{r|l|l|l}
$\begin{array}{c}\text { Case Reports in } \\
\text { Gastroenterology }\end{array}$ & $\begin{array}{l}\text { Case Rep Gastroenterol 2011;5:88-94 } \\
\text { DOl: 10.1159/000322911 }\end{array}$ & $\begin{array}{l}\text { Published online: } \\
\text { February 4, 2011 }\end{array}$ & $\begin{array}{l}\text { O 2011 S. Karger AG, Basel } \\
\text { ISSN 1662-0631 } \\
\text { www.karger.com/crg }\end{array}$ \\
\hline
\end{tabular}

This is an Open Access article licensed under the terms of the Creative Commons AttributionNonCommercial-NoDerivs 3.0 License (www.karger.com/OA-license), applicable to the online version of the article only. Distribution for non-commercial purposes only.

\title{
Therapeutic High-Density Barium Enema in a Case of Presumed Diverticular Hemorrhage
}

\author{
Nonthalee Pausawasdi Mahmoud Al-Hawary \\ Peter D.R. Higgins \\ Department of Internal Medicine, Faculty of Medicine, Siriraj Hospital, Bangkok, \\ Thailand
}

\section{Key Words}

Lower gastrointestinal bleeding · Diverticula $\cdot$ Therapeutic barium enema . Diverticular hemorrhage $\cdot$ Hematochezia $\cdot$ Anemia

\begin{abstract}
Many patients with lower gastrointestinal bleeding do not have an identifiable source of bleeding at colonoscopy. A significant percentage of these patients will have recurrent bleeding. In many patients, the presence of multiple diverticula leads to a diagnosis of presumed diverticular bleeding. Current treatment options include therapeutic endoscopy, angiography, or surgical resection, all of which depend on the identification of the diverticular source of bleeding. This report describes a case of recurrent bleeding in an elderly patient with diverticula but no identifiable source treated successfully with barium impaction therapy. This therapeutic modality does not depend on the identification of the bleeding diverticular lesion and was well tolerated by our 86-year-old patient.
\end{abstract}

\section{Introduction}

Colonic diverticular hemorrhage is the most common cause of massive hematochezia $[1,2]$. Both colonoscopy with endoscopic treatment and angiography with embolization have been shown to be effective for definite diverticular bleeding [3-5]. These methods, however, are not helpful for presumed diverticular bleeding, cases in whom the bleeding source is not visualized endoscopically and the bleeding is not brisk enough to be detected by angiography. Previous reports suggested that therapeutic barium enema could achieve hemostasis in refractory diverticular bleeding $[6,7]$. We present the case of an elderly patient with presumed diverticular bleeding that could not be treated with endoscopic or 


\begin{tabular}{c|l|l|l}
$\begin{array}{r}\text { Case Reports in } \\
\text { Gastruenterology }\end{array}$ & $\begin{array}{l}\text { Case Rep Gastroenterol 2011;5:88-94 } \\
\text { DOI: 10.1159/000322911 }\end{array}$ & $\begin{array}{l}\text { Published online: } \\
\text { February 4, 2011 }\end{array}$ & $\begin{array}{l}\text { O 2011 S. Karger AG, Basel } \\
\text { ISSN 1662-0631 } \\
\text { www.karger.com/crg }\end{array}$ \\
\hline
\end{tabular}

angiographic measures. Her acute bleeding episode was presumably controlled by therapeutic diverticular impaction with high-density barium.

\section{Case Report}

The patient, an 86-year-old woman with Alzheimer's dementia and hypertension, was chronically taking aspirin, amlodipine, and donepizil. She was admitted after an episode of hematochezia with orthostatic hypotension and a hemoglobin of $6.8 \mathrm{mg} / \mathrm{dl}$. Her baseline hemoglobin $12 \mathrm{months}$ prior had been $12.4 \mathrm{mg} / \mathrm{dl}$. She received intravenous fluids and a total of five units of packed red blood cells for resuscitation. The aspirin and amlodipine were stopped. Nasogastric lavage of one liter produced neither blood nor bile. Hematochezia continued and she was transferred to the intensive care unit. She was started on continuous pantoprazole intravenous drip for possible upper gastrointestinal bleeding and prepared for upper and lower endoscopy with polyethylene glycol-electrolyte solution. The upper endoscopy showed multiple small (1-3 mm) antral erosions with no evidence of bleeding, and colonoscopy showed many diverticula scattered throughout the colon, but no blood was seen in the lumen or in the diverticula. No source of bleeding was identified. Her hematocrit stabilized with transfusions and conservative management. She was hospitalized for three days. She was discharged to a nursing home with a hemoglobin of $12.8 \mathrm{mg} / \mathrm{dl}$ and aspirin was restarted the day after discharge.

The patient was re-admitted three days later (day 6) with recurrent hematochezia and a hemoglobin of $10.5 \mathrm{mg} / \mathrm{dl}$. The aspirin was stopped. Enteroscopy, performed on day 7 after the initial bleeding event, was normal to $50 \mathrm{~cm}$ past the pylorus with no evidence of bleeding. Colonoscopy showed multiple diverticula, none specifically bleeding, but maroon blood throughout the colon and maroon blood pooling in the cecum. The terminal ileum was not examined. Continued hematochezia led to a tagged RBC scan which showed increased tracer activity throughout the colon, specifically the ascending, transverse, and descending colon on delayed images at $6 \mathrm{~h}$. The actual site of bleeding was not identified. It was felt by interventional radiologists that angiography would not localize the bleeding site as the bleeding rate was too slow. Capsule endoscopy was performed to further assess the small intestine as the patient continued to pass red blood and clots from the rectum. It showed two $2 \mathrm{~mm}$ angiodysplastic lesions not actively bleeding at 43 and $81 \mathrm{~min}$, a small mucosal break at $89 \mathrm{~min}$, and a few small submucosal hemorrhagic lesions at $120 \mathrm{~min}$, all of which were not actively bleeding. There was no fresh or old blood seen in the lumen. The capsule reached the cecum at $2 \mathrm{~h}$ and $6 \mathrm{~min}$.

Eight hours after the capsule endoscopy was completed, the patient had another episode of bright red blood per rectum. A third colonoscopy was performed after thorough polyethylene glycol preparation. It showed diverticulosis throughout the colon with trace amounts of old blood, but no bleeding site could be identified. Given persistent rectal bleed without evidence of blood in the small intestine or bleeding arteriovenous malformations on capsule endoscopy, we felt that the most likely source of bleeding was colonic diverticula. Our therapeutic options were limited since she was a poor surgical candidate given her age and dementia and since she had not been bleeding briskly enough on the tagged RBC scan for angiography to be helpful. Previous case reports have shown that therapeutic barium enema can successfully stop bleeding in patients diagnosed with presumptive diverticular bleed. For this reason, our patient was taken to the radiology suite for therapeutic high-density barium enema. 1,400 g of E-Z-HD barium sulfate ( $98 \%$ w/w, E-Z-EM, Westbury, N.Y., USA) were dissolved in $300 \mathrm{ml}$ of tap water to prepare a final volume of $800 \mathrm{ml}$ of $171.5 \% \mathrm{w} / \mathrm{v}$ suspension in water, and a Lafayette Aircon XL 3000 disposable air contrast enema kit (Mallinckrodt Inc., St. Louis, Mo., USA) was used to instill the high-density barium by gravity into the colon. Contrast was seen to reach the cecum, and numerous diverticula were noted scattered from the sigmoid colon to the cecum. The patient was asked to change position every 5 min by rolling 90 degrees to the next of four positions over a two-hour period, and at the end of the examination none of the barium could be expelled by the patient (fig. 1). No anti-motility agent such as glucagon was given prior to or during the procedure. Immediately after the procedure, normal saline at $175 \mathrm{ml} / \mathrm{h}$ was initiated. Eighteen hours after the procedure, treatment with polyethylene glycol $17 \mathrm{~g}$ mixed in 8 ounces of water p.o. bid and liberal oral fluids were added in an effort to clear the intraluminal barium and minimize any risk of colonic impaction. Ambulation was encouraged and the patient complied. She continued to pass large amounts of barium per rectum for $48 \mathrm{~h}$ and was able to tolerate clear liquids without any nausea, vomiting, or abdominal pain. She remained free of symptoms worrisome for obstruction, and daily abdominal films were obtained. The abdominal X-ray done $48 \mathrm{~h}$ after treatment showed barium remained in the diverticula throughout the 


\begin{tabular}{r|l|l|l} 
Case Reports in & $\begin{array}{l}\text { Case Rep Gastroenterol 2011;5:88-94 } \\
\text { DOl: 10.1159/000322911 }\end{array}$ & $\begin{array}{l}\text { Published online: } \\
\text { February 4, 2011 }\end{array}$ & $\begin{array}{l}\odot \text { ISSN 1662-0631 } \\
\text { www.karger.com/crg }\end{array}$ \\
\hline
\end{tabular}

colon but was largely cleared from the lumen proper (fig. 2). She remained hemodynamically stable without further evidence of bleeding. Her hematocrit remained stable. She was able to tolerate a regular diet and was discharged. Follow-up in the outpatient clinic two weeks later showed her to be doing well with no recurrence of hematochezia, and her hematocrit was stable at $12.1 \mathrm{mg} / \mathrm{dl}$ on day 16 (fig. 3 ). Follow-up blood counts on days 60,76 and 120 showed no drop in hemoglobin, and the patient, the assisted living center staff, and the patient's children reported no further episodes of bleeding. Aspirin has been discontinued since she was discharged from the hospital.

\section{Discussion}

Diverticulosis is primarily a disease of the elderly, a population with greater incidence of both comorbidities and poor outcomes after surgical resection [8]. Painless rectal bleed is associated with diverticulosis in $15-40 \%$ of patients. Although this bleeding is usually of minor clinical significance, massive bleeding from colonic diverticula may occur in 5\% of patients who have diverticulosis [9]. Bleeding stops spontaneously in $75 \%$ of episodes and in $99 \%$ of patients who are transfused less than four units per day [10]. However, the risk of rebleeding remains $14-53 \%[2,3,11,12]$.

A previous study by Jensen et al. has shown that urgent colonoscopy with endoscopic submucosal injection of epinephrine and bipolar coagulation can prevent recurrent hemorrhage in patients with definite diverticular bleeding. In Jensen et al.'s study, patients who were treated without endoscopic intervention had a rebleeding rate of $53 \%$ [3].

Barium enemas employed for the diagnosis of lower gastrointestinal bleeding were noted by Adams in the early 1960s to coincide in some cases with bleeding cessation [13]. The barium was thought to inspissate in the diverticula and the resulting concretions to tamponade the source of diverticular bleed. A subsequent prospective case series of 22 patients published in 1970 showed 26 of 28 cases of suspected diverticular bleed with a source proximal to the extent of sigmoidoscopy to be acutely controlled by therapeutic barium enema [14]. Thus, before the advent of therapeutic colonoscopy, therapeutic barium enema presented an alternative to conservative management or emergent subtotal colectomy for cases of unrelenting colonic diverticular bleeding.

Recently, interest in therapeutic barium enema has been rekindled for patients with presumed diverticular bleeding. Koperna et al. [15], in a prospective study of 102 patients published in 2001, described therapeutic barium enema in conjunction with sigmoidoscopy as resulting in fewer cases of rebleeding than conservative management in cases where surgery was not indicated or was contraindicated.

Our patient was an elderly woman who had a history of dementia. She had suffered from a refractory presumed diverticular bleed requiring multiple hospital admissions and blood transfusions over a 15-day period. Multiple endoscopic procedures were performed, but failed to demonstrate a definite site of bleeding. Due to her age and medical comorbidities, it was determined that she would be a poor surgical candidate. In addition, it was not possible to localize the bleeding artery by angiography as she was not bleeding briskly on the tagged RBC scan. Capsule endoscopy revealed no actively bleeding lesions in the small bowel and no fresh or old blood was seen in the lumen.

It is difficult to exclude the possibility that one of the non-bleeding lesions in the small bowel caused the bleeding, particularly in the setting of recent aspirin use. However, if the 


\begin{tabular}{r|l|l|l} 
Case Reports in & $\begin{array}{l}\text { Case Rep Gastroenterol 2011;5:88-94 } \\
\text { DOI: 10.1159/000322911 }\end{array}$ & $\begin{array}{l}\text { Published online: } \\
\text { February 4, 2011 }\end{array}$ & $\begin{array}{l}\text { ISSN 1662-0631 } \\
\text { IS. Karger AG, Basel } \\
\text { www.karger.com/crg }\end{array}$ \\
\hline
\end{tabular}

small bowel was the source of acute rectal bleed in this case, we would expect the capsule endoscopy to demonstrate old or fresh heme in the lumen as the patient passed bloody bowel movements and blood clots several hours after the study was performed.

We used a therapeutic high-density barium enema based on previous case reports by Chorost [7] and Matsuhashi [6]. We did not add epinephrine to the high-density barium $(171.5 \% \mathrm{w} / \mathrm{v})$ as used by Matsuhashi [6]. This high-density barium enema technique coincided with the cessation of acute bleeding. However, the use of barium could potentially limit subsequent diagnostic or therapeutic modalities such as angiography. The presence of significant amount of retained barium within the bowel lumen may decrease the sensitivity of angiographic examination due to an overlap of the luminal contrast with bowel wall perfusion. This problem could be minimized by a technique called masking where an initial spot image is used as a subtraction image from all the consequent runs. The efficacy of this technique, however, may be limited when high-density barium is used. The fact that the patient did not rebleed for 4 months after the first bleeding event could probably be attributed to long-term discontinuation of aspirin or the natural history of lower gastrointestinal bleed as it is less likely that the effect of the barium enema would last that long.

Possible complications of barium enema include colonic perforation, mucosal irritation, and thrombosis of the involved vessels; the reported incidence of colonic perforation after barium enema is very low $(0.04 \%)$, and the connection between thrombosis and barium enema is tenuous $[7,16,17]$. A colon weakened by iatrogenic trauma or disease is more likely to perforate than is a normal healthy colon. In addition, tensile strength is impaired in elderly patients, patients receiving long-term steroid therapy, and disease states such as diverticulitis, ischemic bowel, neoplasm, and inflammatory bowel disease [18].

We propose that barium impaction therapy is considered as a therapeutic option in elderly patients with uncontrolled presumptive colonic diverticular bleeding who have failed conservative therapy, particularly for those who are poor surgical candidates. This procedure appears to be safe, tolerable to patients, and easy to perform.

\section{Acknowledgement}

We are thankful to Dr. Susannah Watson for her help with data collection. 


\begin{tabular}{r|l|l|l}
$\begin{array}{r}\text { Case Reports in } \\
\text { Gastruanteriology }\end{array}$ & $\begin{array}{l}\text { Case Rep Gastroenterol 2011;5:88-94 } \\
\text { DOI: 10.1159/000322911 }\end{array}$ & $\begin{array}{l}\text { Published online: } \\
\text { February 4, 2011 }\end{array}$ & $\begin{array}{l}\text { O 2011 S. Karger AG, Basel } \\
\text { ISSN 1662-0631 } \\
\text { www.karger.com/crg }\end{array}$ \\
\hline
\end{tabular}

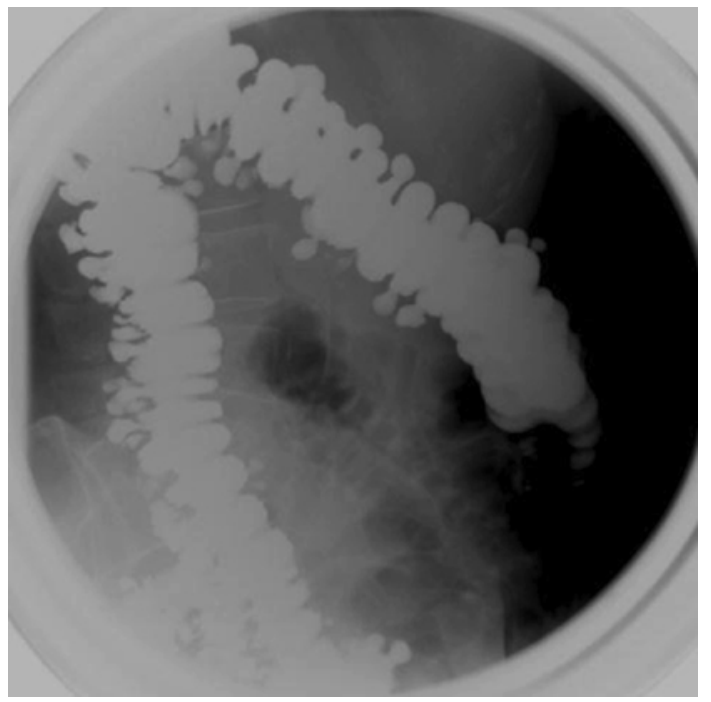

Fig. 1. High-density barium enema with multiple diverticula. The high-density barium $(800 \mathrm{ml}$ of $171.5 \% \mathrm{w} / \mathrm{v}$ suspension in water) was instilled by gravity into the colon. Contrast filled the colon, and after repeated position changes by the patient, numerous diverticula were noted scattered from the sigmoid colon to the cecum.

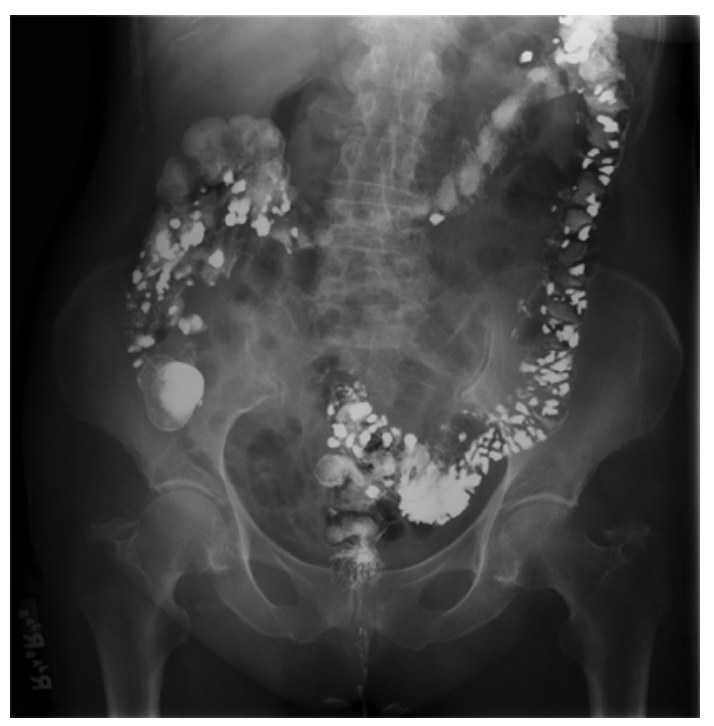

Fig. 2. Remaining barium in the diverticula at $48 \mathrm{~h}$ post procedure. After $48 \mathrm{~h}$ of liberal oral fluids and ambulation to minimize any risk of colonic impaction, the patient was able to tolerate clear liquids without any nausea, vomiting, or abdominal pain. This abdominal X-ray done $48 \mathrm{~h}$ after treatment showed barium remaining in the diverticula throughout the colon but largely cleared from the lumen proper. 


\begin{tabular}{r|l|l|l} 
Case Reports in & $\begin{array}{l}\text { Case Rep Gastroenterol 2011;5:88-94 } \\
\text { DOl: 10.1159/000322911 }\end{array}$ & $\begin{array}{l}\text { Published online: } \\
\text { February 4, 2011 }\end{array}$ & $\begin{array}{l}\odot \text { ISSN 1662-0631 } \\
\text { www.karger.com/crg }\end{array}$ \\
\hline
\end{tabular}

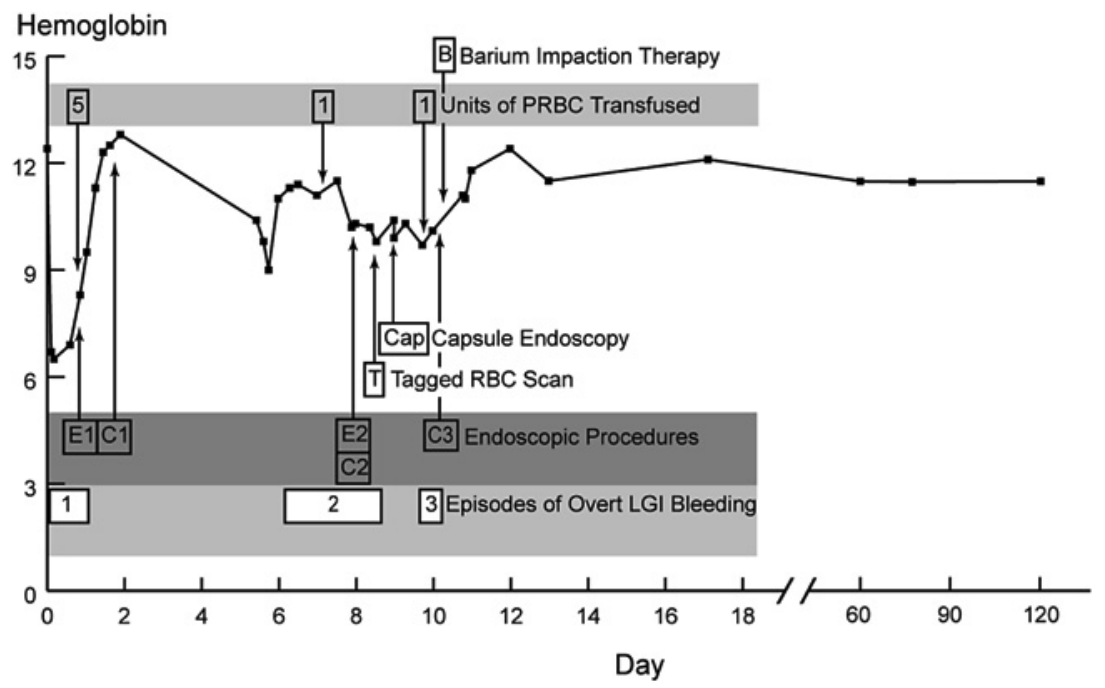

Fig. 3. Time course of bleeding and hemoglobin level. Three bleeding episodes occurred and were assessed endoscopically. Upper endoscopies (esophagogastroduodenoscopy for the first episode and small bowel enteroscopy for the second episode) are designated by the letter $\mathrm{E}$, while colonoscopies are designated by the letter $\mathrm{C}$. The tagged red blood cell scan is designated by the letter $\mathrm{T}$, capsule endoscopy is designated by 'Cap', and the numbers indicate the number of units of packed red blood cells transfused. The barium impaction therapy on day 10 is designated by the letter $\mathrm{B}$.

\section{References}

$\checkmark 1$ Browder W, Cerise EJ, Litwin MS: Impact of emergency angiography in massive lower gastrointestinal bleeding. Ann Surg 1986;204:530-536.

2 Gostout CJ, Wang KK, Ahlquist DA, et al: Acute gastrointestinal bleeding. Experience of a specialized management team. J Clin Gastroenterol 1992;14:260-267.

3 Jensen DM, Machicado GA, Jutabha R, Kovacs TO: Urgent colonoscopy for the diagnosis and treatment of severe diverticular hemorrhage. N Engl J Med 2000;342:78-82.

-4 Quinn W: Gross hemorrhage from presumed diverticular disease of the colon. Ann Surg 1961;153:851-860.

5 Gordon RL, Ahl KL, Kerlan RK, et al: Selective arterial embolization for the control of lower gastrointestinal bleeding. Am J Surg 1997;174:24-28.

6 Matsuhashi N, Akahane M, Nakajima A: Barium impaction therapy for refractory colonic diverticular bleeding. AJR Am J Roentgenol 2003;180:490-492.

7 Chorost MI, Fruchter G, Kantor AM, Wu J, Ghosh BC: The therapeutic barium enema revisited. Clin Radiol 2001;56:856-858.

8 Uden P, Jiborn H, Jonsson K: Influence of selective mesenteric arteriography on the outcome of emergency surgery for massive, lower gastrointestinal hemorrhage. A 15-year experience. Dis Colon Rectum 1986;29: $561-566$.

9 Simmang CL, Shires GT III: Diverticular disease of the colon; in Feldman M (ed): Sleisenger and Fordtran's Gastrointestinal and Liver Disease, ed 7. Philadelphia, Saunders, 2002, p 2105.

10 Imbembo A, Bailey R: Diverticular disease of the colon; in Sabiston D (ed): Textbook of Surgery, ed 14. Philadelphia, Churchill Livingstone, 1992, p 910.

11 McGuire HH Jr: Bleeding colonic diverticula. A reappraisal of natural history and management. Ann Surg 1994;220:653-656.

12 Elta GH: Urgent colonoscopy for acute lower-GI bleeding. Gastrointest Endosc 2004;59:402-408.

13 Adams JT: The barium enema as treatment for massive diverticular bleeding. Dis Colon Rectum 1974;17: 439-441.

14 Adams JT: Therapeutic barium enema for massive diverticular bleeding. Arch Surg 1970;101:457-460. 
15 Koperna T, Kisser M, Reiner G, Schulz F: Diagnosis and treatment of bleeding colonic diverticula. Hepatogastroenterology 2001;48:702-705.

16 Hakim NS, Sarr MG, Bender CE, Nivatvongs S: Management of barium enema-induced colorectal perforation. Am Surg 1992;58:673-676.

17 Miller RE, Skucas J, Violante MR, Shapiro ME: The effect of barium on blood in the gastrointestinal tract. Radiology 1975;117(3 pt 1):527-530.

18 Williams SM, Harned RK: Recognition and prevention of barium enema complications. Curr Probl Diagn Radiol 1991;20:123-151. 